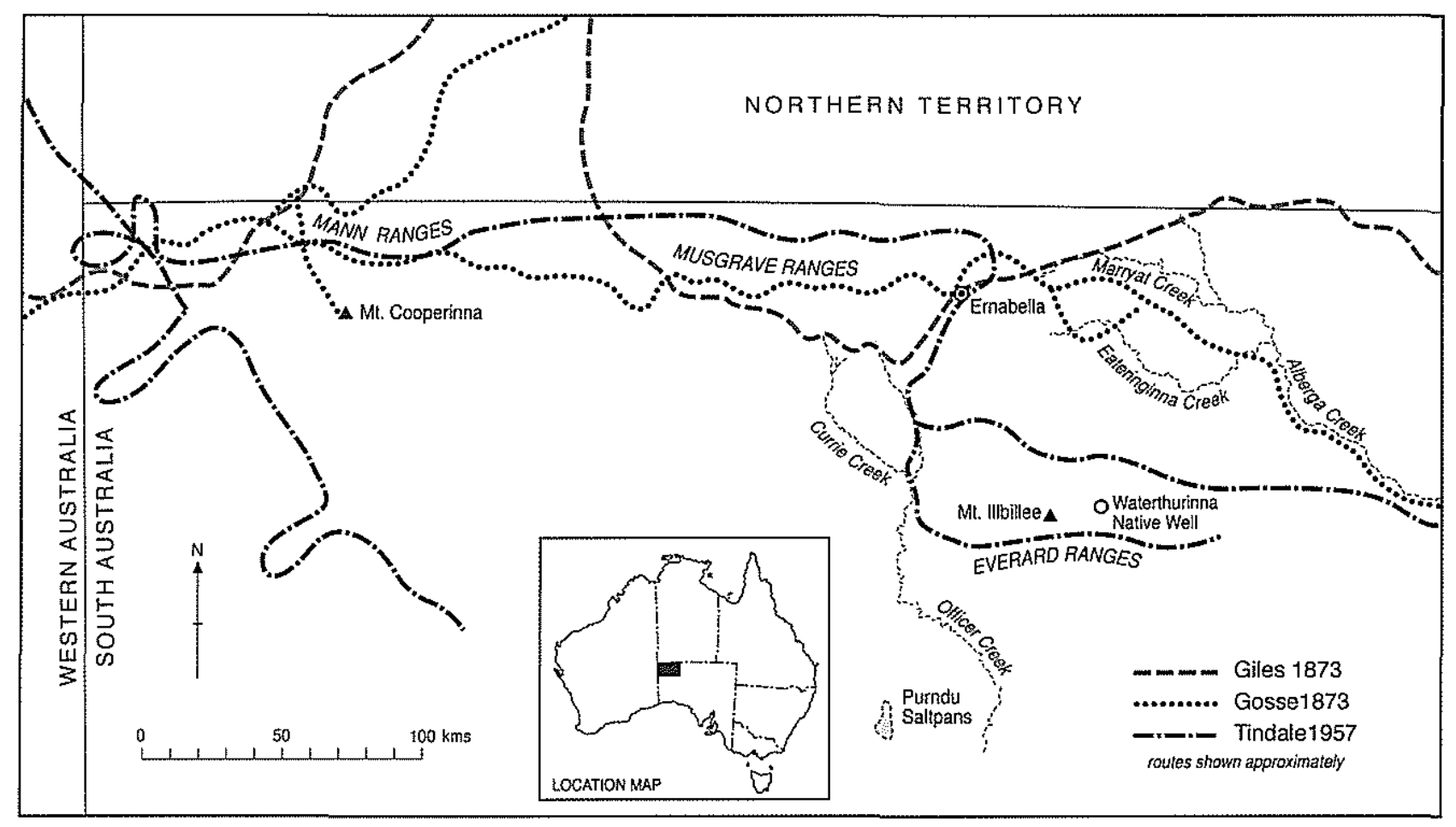

Map 1: Placenames in the Western Desert of South Australia 


\title{
15 'WHAT NAME?': THE RECORDING OF INDIGENOUS PLACENAMES IN THE WESTERN DESERT OF SOUTH AUSTRALIA
}

\author{
Paul Monaghan
}

I would like to make a few brief comments on an issue arising from my current research on placenames in the north-west of South Australia (see Map 1). ${ }^{1}$ While the research considers both Indigenous placenaming practices and those names imposed by colonisers, an early problem is suggested by the fact that nearly all Indigenous placenames on record have been recorded by non-Indigenous people. Who recorded the names and under what conditions, what sorts of features had their names recorded, and what types of inaccuracies occurred? These are the main questions I will now briefly address.

(i) The first major explorations to pass through the north-west region were conducted in the 1870 s by Ernest Giles, John Forrest and W.C. Gosse. In general, Indigenous placenames were overlooked - either because contact with locals was minimal or non-existent, or colonial naming practices in English, commemorating an influential colonial figure, expedition member, relative or friend, predominated. A few names, however, were recorded by Gosse towards the end of his expedition, largely because of increased contact with locals. As can be seen from the following example though, the Indigenous name remained the marked case:

Charlie ... showed me a hole of water thirty yards long, six wide, and four deep, which I have called by its native name, Appatinna. (1874:22)

Charlie, described as a blackfellow 'who could speak a few words of English' (1874:2122 ), was not attached to the expedition but was met within the vicinity of the waterhole. This type of incidental meeting, with communication in Pidgin English, was fairly typical of what

\footnotetext{
1 My thanks go to Rob Amery who made some helpful suggestions to a draft version of this paper. Thanks also to Jane Simpson for editorial comments on a later draft. Of course, any remaining errors are my own.

This research has arisen as part of $\mathrm{PhD}$ I am currently undertaking at the University of Adelaide. At the present stage of its genesis, my thesis examines the wider cultural contexts in which Indigenous and non-Indigenous placenames have been recorded and used in the north-west of South Australia. It is particularly concerned with the linguistic 'construction' of land-language relations and how this impacts on current Native Title issues.
}

L. Hercus, F. Hodges and J. Simpson, eds, The Land is a Map: placenames of Indigenous origin in Australia, 202-206.

Canberra: Pandanus Books in association with Pacific Linguistics, 2002.

(C) Paul Monaghan 
was to follow, with names of water-related features figuring prominently. Nearly all of the names recorded by Herbert Basedow in 1903, for example, are in this category (see Basedow 1914).

(ii) Under the instruction to "name all the hills piled by you where not already named, preserving as far as possible the native names' (PRG 10/6), the surveyor John Carruthers set out to triangulate the north-west region in 1888. His survey plan from the years 1888-1892 (Adelaide Surveyor General's Office, n.d.[1893?]) contains a wealth of Indigenous names for a broad range of geographical features, many of which were no doubt recorded by Carruthers himself. But how were these names recorded? A journal entry for 3 July 1889 states:

Built stone pile on 'Cooperinna' hill ... Met some Natives this morning and through our interpreter Tommy Carrunda obtained the Native name of this hill. (PRG 10/3)

But this approach was not always successful, as the following account reveals:

Our interpreter Tommy Carrunda had some difficulty in understanding the meaning of a lot of their words ... Unfortunately Tommy could not make them understand that we wanted their Native names for our hills and other prominent features. (PRG 10/7)

Apart from the use of interpreters, Carruthers used Pidgin English to gather the names directly from Indigenous people, if the following account by Basedow is anything to go by:

Mr. W.R. Murray, one of J. Carruthers' party, tells me that an appropriate native name was wanted for an imposing, bare, granite mound in the heart of the Everard Ranges. An old warrior was consequently addressed as follows: 'What name that one hill, Billy?' The old man looked up smirkingly at the white men and, as they usually do, repeated the last syllables of the query as near to the original as he could. 'Ill Billy' came the guttural reply. 'No, that one hill, Billy,' shouted Carruthers. 'Ill Billy' shouted the old chap with a pitiful smile and a peculiar gesture with his hands. 'Well, if it must be,' said Carruthers, 'we shall name the hill Illbillee.' (1914:233)

And so it appeared on the survey plan, and on subsequent maps. While the humour of this account rests on a pun, it also points to the degree of uncertainty or ambiguity that could arise during the name recording process. While it is possible to trace the likely meaning of 'Illbillee'(between Papunya and Kintore is a place Ilpilli, where ti-trees are a prominent feature in the landscape (David Nash pers. comm.); Cliff Goddard (1992) gives 'ilpili' as 'ti-tree'), it is not so easy to determine whether the recording of this name rests on a misunderstanding or merely a humorous aside based on a coincidence. Perhaps we will never know for certain, but it is likely that an element of both was involved.

(iii) An interesting question is raised by David Lindsay's recording of 'Purndu Saltpans' (1893:12) in 1891, while leading the Elder Expedition. Upon arriving at a saltpan with Billy, an Everard Range local who had been 'following' the party, Lindsay learned that it was 'purndu' and recorded the name of the feature as Purndu Saltpans. In Pitjantjatjara/Yankunytjatjara (P/Y), however, pantu is a general term for saltpan; so it seems we have the case of a geographical feature in the Indigenous language being recorded as its placename. At present an alternative Indigenous name for this feature is not known to me, and one does not appear on the South Australian Gazetteer, so the question remains: 'Should this be taken as an Indigenous name, a name imposed by colonists, or in some sense a joint English-P/Y construction?' Of course, the possibility that it is both general term and placename should not be ruled out at this stage (that is, before fieldwork is undertaken). 
(iv) Probably more in the category of inaccuracy rather than error, most names recorded up to this point were missing a number of retroflex and nasal sounds that were not picked up by the native English speakers. A 'system of orthography for native names of places' put together by the Royal Geographical Society in London was available to some travellers, and this did seem to regularise some of the orthographic practices (see 'Handbook of Instructions for ... the Elder Scientific Exploring Expedition', 1891:3536). Largely though, the names recorded were influenced by English writing practices. On Carruthers' survey plan we find for instance:

\section{Eateringinna}

\section{Waterthurinna}

\section{Cooperinna}

(v) After the explorers, surveyors, prospectors and scientists came the anthropologists, and it is with their arrival that we find a marked increase in the recording of placenames. Moreover, the work was carried out, particularly by Norman Tindale, in what seems a more systematic and rigorous fashion. Tindale set out to record as many names as he could, employed a more detailed orthography (although he did struggle with it), and often revised the spelling of names previously recorded by others. During field trips in 1933 and 1957 he gathered names in the standard way of asking informants while at a location, but he also broadened this to include names heard while talking about, as he puts it, 'totems, ancestral legends \& placenames' (1933:59), and from the crayon drawings also collected. As his journals show, he was careful to record the names and cross-check them later while on a peak or high point:

The native pointed out various native places of interest \& helped locate places of which I had previously only vague ideas as to direction. Thus list of native names of places is growing. (Tindale 1933:341)

There are many other examples I could have chosen to illustrate this point.

Part of my task with Tindale's names is to locate any blind spots in his recording as well as to consider his reliability given the difficulties he faced as an early researcher in this area. At one point he corrects a name on Carruthers' survey plan, noting that the recording Pinundinna Hill, south of the Musgrave Ranges, is 'in error' and that it is in actual fact 'Inanja'. While this may have been an error on Carruthers' part (which I have not been able to establish yet), it could also simply be an alternative name - an important aspect of Indigenous naming practices that Tindale does not seem to be aware of at this point. In general he seems to have been content with one name and to move on to the next feature.

(vi) Finally, I should mention the work of Bill Watt from the South Australian Geographical Names Advisory Committee. In the late 1980s Bill conducted fieldwork in the north-west region, recording placenames and verifying those already on the South Australian Gazetteer. Importantly he was helped with the orthographic aspects of this work by Cliff Goddard, a linguist who was working at that time in the northwest region. This approach, introducing GPS (Global Positioning System) technology and a culture/language specialist into the official recording process, obviously stands in stark contrast to the first attempts of early colonists to record the locations and names of 'native places'. 
In conclusion it should be evident that the recording of placenames in the north-west has developed from incidental and haphazard to well organised and thorough over time. Nevertheless, questions of accuracy still remain and work needs to be done in checking the names already recorded.

\section{REFERENCES}

Basedow, Herbert, 1914, Journal of the Government north-west expedition (1903). Royal Geographical Society of Australia, SA Branch Proceedings 15:57-242.

Carruthers, John, (1888-1890 MS), Journal of John Carruthers. State Library of South Australia, Mortlock Library of South Australiana: PRG:10/3.

- (MS), Letters received from the Surveyor General, 1882-1895. State Library of South Australia, Mortlock Library of South Australiana: PRG:10/6.

- (MS), Papers of John Carruthers. State Library of South Australia, Mortlock Library of South Australiana: PRG:10/7.

Goddard, Cliff, 1992, Pitjantjatjara/Yankunytjatjara to English Dictionary. 2nd edition. Alice Springs: IAD.

Gosse, W.C., 1874, Report and diary of Mr W.C. Gosse's central and western exploring expedition, 1873. South Australian Parliamentary Paper No. 48.

Handbook of Instructions for the Guidance of the Officers of the Elder Scientific Exploring Expedition to the Unknown Portions of Australia, 1891. Royal Geographical Society of Australia, South Australian Branch. Adelaide: W.K. Thomas \& Co.

Lindsay, David, 1893, Journal of the Elder exploring expedition, 1891. South Australian Parliamentary Paper No. 45.

Surveyor General's Office, n.d.[1893?], Map of country in the north-west portion of the province triangulated by J. Carruthers during 1888-1892. Adelaide.

Tindale, Norman, 1933, Journal of an anthropological expedition to the Mann and Musgrave Ranges, north west of South Australia, May-July 1933 and a personal record of the anthropological expedition to Ernabella, Aug 1933. MS. South Australian Museum: AA 338/1/9. 